\title{
A Cashless Society for all - Surge of Mobile Payments in India
}

\author{
Aakash Kamble* and Supriya Desai \\ Indira Global Business School, India
}

Submission: February 01, 2020; Published: February 06, 2020

*Corresponding author: Aakash Kamble, Assistant Professor, Indira Global Business School, Pune, India

Abstract

Mobile payments have witnessed unprecedented growth in recent years owing to the penetration of smartphone technology among the population across the world. Digital payments in India have grown since the inception of innovative Unified Payment Interface (UPI) system by the government. With rise in the transactions over UPI, the instances of cyber frauds have also increased. Timely interventions by the regulators, financial organization and consumers can prevent the rising cyber security concerns and pay way for a truly cashless society.

Keywords: Mobile payments; Digital payments; UPI; India; Financial transactions; Technology adoption

Abbrevations: UPI: Unified Payment Interface; RBI: Reserve Bank of India

\section{Introduction}

Figure 1: UPI Transactions

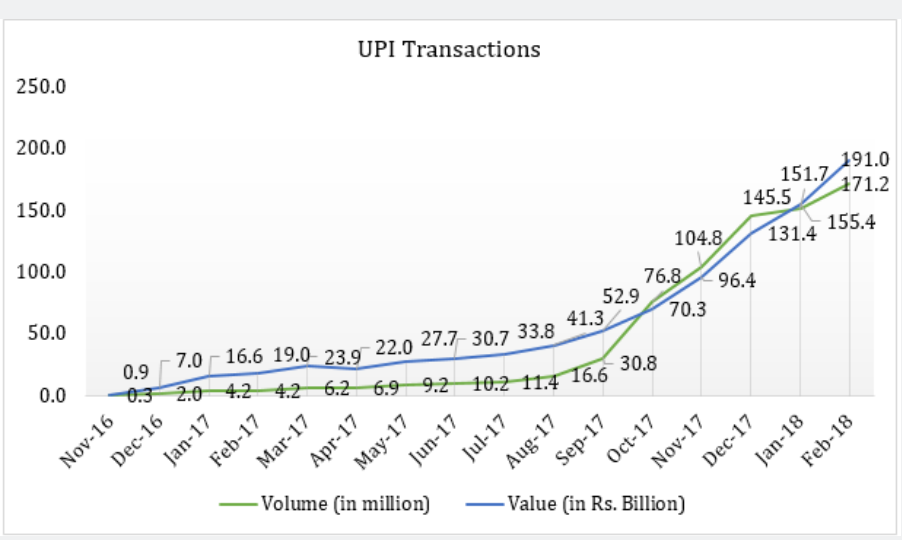

Past decade has witnessed rapid adoption of mobile phones across the globe and their role in professional activities [1]. This has led to heightened attention by merchants, financial institutions and telecommunication operators on increasing the mobile enabled services offered to consumers [2]. The mobile enabled services have eased the way communication, interactions and transactions are handled by the consumers. On financial transactions front mobile payment services are at the forefront of providing financial services to consumers and digitizing the payment transactions. The Indian digital payment industry was poised to grow by 10 times to $\$ 500$ billion by 2020 contributing
15 percent to the GDP [3]. The global reach of internet will reach to almost three billion people covering a staggering 65 percent of world's population by 2020 [4]. Indian consumers and industries have adopted mobile payment services in the form of mobile banking, mobile wallets and Unified Payment Interface (UPI), etc. Unified Payment Interface also popularly known as UPI in India is a system that empowers consumers to link multiple bank accounts into a single mobile application of any participating bank, in turn merging several banking features with fund routing and merchant payments. UPI transactions in India have seen stupendous growth in terms of volumes of transaction and value of transactions. The 
Figure 1 represents volume in terms of usage in million and value in Indian Rupees (Rs.) billion for a period from November 2016 to February 2018. As seen in the figure 1, there is been a rise in the number of transactions done since November 2016 after the demonetization of Indian currency by Government of India. The total value transacted has also grown and in the month of February 2018 it was pegged at INR 191 billion [5]. The acceptance and adoption of unified payment interface has been able to percolate across geographies, population and sectors of India with leading the digital payment insurgence from forefront. Three years since demonetization, digital payments in India have seen consistent growth at a compound annual growth rate (CAGR) of $12.7 \%$, while the mobile wallet market is expected to continuously grow at a CAGR of $52.2 \%$ by volume between 2019-23, according to a recent report by KPMG [6]. Unprecedented increase in digital transactions/payments coupled with accelerating rise in downloads and use of electronic wallets by Indian consumers have driven this sector.

\section{The Concern}

Digitizing the complete economy, moving towards cashless society is the end-goal, the regulators need to understand the present security and fraud control frameworks in India. Overstressing these systems and frameworks may lead to severing the connections and trust of consumers in case of malpractices. At present the digital and mobile payment scenario in India is at a nascent stage with new innovations entering the commercial market on a regular basis. Maturity of this sector will depend on the acceptance and adoption of this technology by the regulators, finance professionals and the consumers. Threats over internet in case of financial transactions may expose the cyber security framework of the banking system resulting in online fraud, information theft, and malware or virus attacks. Digital payment frauds account for about half of all bank frauds in India. The increasing number of frauds was also recently highlighted in the Rajya Sabha, where it was said that 1,367 frauds in FY 2016-17, 2,127 in FY 2017-18, and 1,477 frauds in FY 2018-19 were reported with regard to ATM/debit card, credit card and internet banking transactions of more than Indian Rupees 100,000 [6]. To tackle this rising concern a robust regulatory framework, an effective customer redressal framework, foolproof security measures to enable confidence and trust, incentives for larger participation and benefits similar to cash transactions are some measures that can help ensure long-term success for digital payments.

\section{Conclusion}

Financial transaction instruments such as debit/credit cards are becoming popular in India among the young generation despite the security concerns leading the way as the primary growth drivers. According to Reserve Bank of India [7], UPI/IMPS payment systems are likely to register an average annualized growth of over 100 percent. With shared responsibility shouldered by the regulators, government, financial institutions and consumers, digital payment ecosystem can be strengthened reducing the risk of frauds. Also, RBI has forecast a $50 \%$ increase in mobile-based payment transactions. Payment systems such as UPI/IMPS are likely to register average annualized growth of over $100 \%$, according to RBI's 2021 vision document. Though cyber security and digital payment fraud cases pose a great risk, the digital payment ecosystem can surely be strengthened, with organizations, users, and the government sharing the responsibility of securing the digital payments. NXP, being the market leader in credit cards, makes it a top priority to secure the digital payment infrastructure and maintain the privacy of its customers.

\section{References}

1. Liébana-Cabanillas F, Ramos de Luna I, Montoro-Ríos F (2017) Intention to use new mobile payment systems: a comparative analysis of SMS and NFC payments. Economic Research-Ekonomska Istraživanja 30(1): 892-910.

2. Humbani M, Wiese M (2018) A cashless society for all: Determining consumers' readiness to adopt mobile payment services. Journal of African Business 19(3): 409-429.

3. Shah A, Kaushik V, Roongta P, Jain C, Awadhiya A (2016) Digital payments 2020: The making of a $\$ 500$ billion ecosystem in India. The Boston Consulting Group.

4. Sobti N (2019) Impact of demonetization on diffusion of mobile payment service in India. Journal of Advances in Management Research.

5. Reserve Bank of India (2019a) Electronic Payment System. Mumbai.

6. Gupta S (2020) Opinion | Cybersecurity a critical challenge for india's digital payments ecosys.

7. Reserve Bank of India (2019b) Payment and Settlement Systems in India: Vision 2019 - 2021, New Delhi. 
Your next submission with Juniper Publishers

$$
\text { will reach you the below assets }
$$

- Quality Editorial service

- Swift Peer Review

- Reprints availability

- E-prints Service

- Manuscript Podcast for convenient understanding

- Global attainment for your research

- Manuscript accessibility in different formats

( Pdf, E-pub, Full Text, Audio)

- Unceasing customer service

Track the below URL for one-step submission https://juniperpublishers.com/online-submission.php 